\title{
Servius, Cato the Elder and Virgil
}

\author{
Christopher S $\mathrm{MITH}$
}

C. Smith, British School at Rome, University of St Andrews, cjs6@st-and.ac.uk

\begin{abstract}
This paper considers one of the most significant of the authors cited in the Servian tradition, Cato the Elder. He is cited more than any other historian, and looked at the other way round, Servius is a very important source for our knowledge of Cato. This paper addresses the questions of what we learn from Servius' use of Cato, and what we learn about Virgil?
\end{abstract}

Servius, Cato the Elder, Virgil, Aeneas

\begin{abstract}
Cet article envisage la figure du principal auteur cite dans la tradition servienne, Caton l'Ancien. C'est l'historien le plus cité par Servius et, à l'inverse, Servius est une source très importante pour notre connaissance de Caton. Cet article revient sur l'utilisation de Caton par Servius et sur ce que Servius nous apprend sur Virgile.
\end{abstract}

Servius, Catone l'Ancien, Virgile, Énée

The depth of knowledge and understanding underpinning Virgil's approach to Italy in the Aeneid demonstrates that he was a profoundly learned poet; and it was a learning which was clearly drawn on deep knowledge and understanding of previous writers in many different traditions ${ }^{1}$. Virgil's learning was indeed such that he provoked a tradition of commentary, and thus his erudition was augmented by the observations, disagreements and elucidations of subsequent generations, some of which permits us to glimpse the writings of those whose own work has not survived in total. Indeed, the fact that the preponderance of fragmentary historical writing, that is the work of historians whom we know only from citations by other writers, relates to the earliest history of Rome is demonstrably a product, in part, of the influence of Virgil, and the enduring signif-

1. For Virgil as a learned poet see Gell. 5.12.13; Serv. A. 6.1 (Virgil is everywhere full of knowledge, scientia plenus); and repeatedly in Macrobius. For Virgil as a philosopher and compendium of knowledge in Antiquity and into the Renaissance, see the texts gathered at Ziolkowski - Putnam 2008, p. 463-7. See Ferriss-Hill 2001 for a demonstration of Virgil's use of Sabellic glosses (even above the two found by Servius at A. 7.517 and 7.684), and Poccetti 2004 for other signs of linguistic knowledge in Virgil and Servius. icance of his account of the beginnings of Rome. Our assumption that the historians focused on the earlier history and then passed rapidly over the early Republic is partly shaped by this tendency in the citing authorities ${ }^{2}$.

The commentary which has survived most extensively and which offers the most significant example of the genre, is that attributed to Marius or Maurus Servius Honoratus, whose $4^{\text {th }}$ century work was added to at a later stage to create what we call Servius Danielis or Servius Auctus. Both versions are likely to have been heavily indebted to a slightly earlier commentator, Donatus, and he probably depended on an even earlier tradition, dominated by the early third century writer Aemilius Asper ${ }^{3}$. It appears that Servius simplified

2. See Pellizzari 2003, p. 222-225; Ramires 2004; FRHist 1.38-45 for the evidence, and Rich (forthcoming) for a fuller account; see also below.

3. On Servius see Kaster 1988, p. 169-197, as part of a broader account of the grammarians, and Fowler 1997. On Macrobius' representation of Servius, arguing that the Saturnalia systematically misrepresents Servius, who was probably therefore dead, see Cameron 2011, p. 231-272c; and idem 567-626 for an account of pagan scholarship on Virgil, including important comments on the relationship between Servius and DS. For Aemilius Asper see idem 410-411, 593-594. 
this tradition, and the annotator tried to restore some of the variety. A comparison between Servius and Servius Danielis shows that the later author has added citations, and from a larger number of authors ${ }^{4}$.

This paper considers one of the most significant of the authors cited in the Servian tradition, Cato the Elder. He is cited 38 times in the combined tradition, much more than any other historian, and looked at the other way round, Servius is a very important source for our knowledge of Cato ${ }^{5}$. So what do we learn from Servius' use of Cato, and what do we learn about Virgil ${ }^{6}$.

\section{AENEAS' ARRIVAL NEAR ROME}

The Virgilian story of Aeneas' arrival near Rome is reasonably clear. Aeneas has wandered far, but driven on by omens and needing to be sure of his landfall, he travels up the west coast of Italy to somewhere near Lavinium. There all the omens come true, and he seeks a friendly settlement. He is accepted by Latinus, but Latinus's wife and his prospective son-in-law Turnus overturn the welcome, and war ensues. Latinus withdraws into his palace and Turnus is killed by Aeneas at the end of the poem. The story is effective and dramatic, but it is very much a compression of the historical narratives. As we can see from Livy and Dionysius of Halicarnassus there were various more complex stories, and Virgil has collapsed the time frame for dramatic effect.

The Catonian version of the story is difficult to identify, and the citations appear contradictory. However it is clear that by the early second century BC there was already a complex version of Aeneas'

4. Rand 1916; Lloyd 1961; Goold 1970; Pellizzari 2003, p. 6-15; Sharrock 2008 who sums up well "no doubt Donatus' commentary was a work of considerable skill and sensitivity, but the DS text is only an echo of it, in which there is much that cannot be heard properly."

5. FRHist 1.38-44; 119-122; Lloyd 1961.

6. The research presented here draws heavily on FRHist The entry on Cato the Elder is by T. J. Cornell. I have followed our typographic convention that "all material attributed by the citing authority to the lost source is printed in bold type. Where it purports to be a verbatim quotation, the quoted words are in bold italic type. Where it is not represented as a verbatim quotation, but just as a report or paraphrase of content, the attributed matter is printed in bold roman type » (bold and italics as in original), FRHist 1.15. arrival and one which reflected different views of foreign cultural superiority and the prehistory of the Latins. ${ }^{7}$ Let us first consider the passages relating to the Trojans' arrival at the river Numicus.

F4a, b

*F4 ( =Jordan I F8, Peter F4, Chassignet I F7, Cugusi F10)

a Serv. Aen. 1.5

(V) multa quoque et bello passus, dum conderet urbem $(\mathrm{DS}+\mathrm{S})$ tres hic sunt significationes : aut enim Troiam dicit, quam, ut primum in Italiam uenit, fecit Aeneas .

. . Troiam autem dici quam primum fecit Aeneas et Liuius in primo et Cato in originibus testantur . . . aut Laurolauinium . . . aut Romam . . .

b Serv. Aen. 7.158-9

(V) moliturque locum, primasque in litore sedes castrorum in morem pinnis atque aggere cingit. (DS+S) et sciendum ciuitatem, quam primo fecit Aeneas, Troiam dictam secundum Catonem et Liuium.

F5

F5 ( =Jordan I F9, Peter F8, Chassignet I F8, Cugusi F1 1) =Sisenna 26 F2

Serv. Aen. 11.316

(V) est antiquus ager Tusco mihi proximus amni (DS+S) ... unde sequenda est potius Liui, Sisennae, et Catonis auctoritas: nam paene omnes antiquae historiae scriptores in hoc consentiunt. Cato enim in originibus dicit Troianos a Latino accepisse agrum qui est inter Laurentum et castra Troiana. hic etiam modum agri commemorat et dicit eum habuisse iugera duo milia septingenta.
7. See now Fabrizi 2012, p. 31-71 for an attempt to reconstruct Ennius' version as a relatively peaceful arrival, and the amalgamation of Trojans with locals; Stok 2004 for a general account of the war in Italy, and for Servian scepticism and realism regarding the problematic source material. 
F6 (=Jordan I F10, Peter F9, Chassignet I F9, Cugusi F12a)

a Serv. Aen. 1.267-8

(V) at puer Ascanius, cui nunc cognomen Iulo additur...

$(\mathrm{DS}+\mathrm{S})$ secundum Catonem historiae hoc habet fides:

Aeneam cum patre ad Italiam uenisse et propter inuasos agros contra Latinum Turnumque pugnasse, in quo proelio periit Latinus. Turnum postea ad Mezentium confugisse eiusque fretum auxilio bella renouasse, quibus Aeneas Turnusque pariter rapti sunt. migrasse postea in Ascanium et Mezentium bella, sed eos singulari certamine dimicasse.

(DS) et occiso Mezentio Ascanium,

sicut L. Caesar scribit, Iulum

(S) et occiso Mezentio

coeptum uocari, uel quasi ioßódov,

Ascanium Iulum coeptum

uocari, a prima barbae lanugine

id est, sagittandi peritum, uel a

quae ei tempore uictoriae

prima barbae lanugine, nascebatur. quam ioviov

Graeci dicunt, quae ei tempore

uictoriae nascebatur.

b Hygin. fab. 260

Eryx Veneris et Butae filius fuit, qui occisus ab Hercule est. monti ex sepultura sua nomen imposuit, in quo Aeneas Veneris templum constituit. in hoc monte dicitur etiam Anchises sepultus, licet secundum Catonem ad Italiam uenerit

c Serv. Aen. 1.570

(V) siue Erycis fines regemque optatis Acesten (DS+S) in hoc autem monte dicitur etiam Anchises sepultus, licet secundum Catonem ad Italiam uenerit. d Serv. Aen. 3.710-11

(V) ... hic me, pater optime, fessum deseris, heu! ...

(DS+S) ut supra diximus, secundum Vergilium; nam Cato eum (eum in originibus DS) ad Italiam uenisse docet.

e Serv. Aen. 4.427

(V) nec patris Anchisae cineres manesue reuelli (DS+S) ... sciendum sane Varronem dicere Diomedem eruta Anchisae ossa filio reddidisse, Catonem autem adfirmare quod Anchises ad Italiam uenit (uenerit DS). tanta est inter ipsos uarietas et historiarum confusio.

There is a widespread tradition that the first city founded by Aeneas in Italy was called Troia ${ }^{8}$. It is interesting that this story comes right at the beginning of Livy and the Aeneid, if we read the urbs as Troia here - the alternatives are Lavinium and Rome. There is every likelihood that Cato's narrative arrived at Aeneas' arrival in Italy fairly swiftly, and so Virgil may have wanted to reflect that in his cleverly ambiguous phrasing. The foundation of a camp near the shore is the first step, but it was an insufficient step. The Trojans needed land, and in F5 we see the grant of additional territory. The size of this original grant is disputed (on the basis, clearly, of no evidence whatsoever), but the location is also complicated. Virgil uses Laurens as an adjective for Lavinium, but the existence of somewhere actually called Laurentum may be a later extrapolation. It may be an attempt to give a name to a site which did not yet exist; in the imperial period, there was a Vicus Augustanus Laurentum ${ }^{9}$. Whether Laurentum was imagined by Cato to be somewhere distinct from Lavinium is difficult to say. So we may see an imperial period gloss on Cato's vaguer indications; or we may have to acknowledge that this area was already full of references to the Aeneas story.

9. On Lavinium and its various names see Horsfall 1987; Nonnis 1995-1996; Cooley 2000; Mastroiacovo 2004 and Grandazzi 2010 for the religious landscape between Rome, Lavinium and Alba Longa.
8. Livy 1.1.4 (cited here) ; DH 1.53.3 ; Festus p. 504 L.; App. reg. 1.1; Dio fr. 4.4; Serv. Aen. 9.47 and see below on the castra Troiana. The site should be near Lavinium at the mouth of the river Numicus and is sometimes associated with the site at Torvaianica, found by Castagnoli, which is usefully summarised at Ceccarelli - Marroni 2011, p. 242-244). For the various Troys, see Musti 1988, p. 95-122. The Dionysian version is discussed by Vanotti 1995. 
So far the account seems somewhat consensual, but a different note is struck in F6. There are two crucial aspects of this passage. First it is clear that Cato thought that Anchises survived as far as Italy, instead of passing away in Sicily. This was startling to the commentators, but may have been the earliest version; Naevius has been taken to say the same ${ }^{10}$. More controversially, the suggestion in the fragment that Latinus fought alongside Turnus against Aeneas consistently from the beginning is at odds with a number of other Catonian fragments, although it is closer to Virgil. Our suggestion has been that the $O G R$ has a version of the Catonian narrative which is closer to what he wrote, that Latinus led out his forces against the invasion led by Aeneas, but seeing the organization of the opposition, held a parley, learnt of their wanderings and their piety, and offered a truce, and his daughter's hand in marriage. Turnus, who had been betrothed to Latinus' daughter, gathers the Rutulians and gives battle. Latinus and Aeneas overcome him, although Latinus is killed ${ }^{11}$. Similarly, Dionysius of Halicarnassus (1.56) has Latinus step back from engaging in battle when he sees the good order and resolution of the Greeks. This means that F6, which implies that Latinus and Turnus were jointly opposed to Aeneas, is at odds with the other fragments, which seem to suggest that Latinus comes to terms with Aeneas, and then Aeneas and Latinus have to deal with Turnus. It has been suggested that in F6, the Virgilian narrative has contaminated the commentators' memory of the Catonian version.

We can also see, though, what Virgil has done with the character of Latinus. Instead of a version of Realpolitik, as we see in our reconstruction of Cato's narrative, in which a recognition of the qualities of the Trojans leads to a shift of marriage alliance, Virgil depicts a weak, vacillating leader, hiding and shirking responsibility, unable to manage his wife, or his people. Latinus' change of mind from opposition to accommodation is perhaps too sudden and enthusiastic. He offers a lot very quickly, but this is also a critical moment in the divine machinery. The alliance with Turnus runs into unfavourable and terrifying omens. The

10. Naevius fr. $3 \mathrm{M}$ and also in Strabo 5.229; OGR 10.5, 11.3, and 13.3, and Dionysius of Halicarnassus knows this variant, 1.64.5.

11. OGR 12.5-13.5= F10; and below F7. oracle of Faunus pronounces the impossibility of the union - a foreigner is required; Juno's wrath provokes Amata's madness and war ensues ${ }^{12}$.

Interestingly, when Amata argues with Latinus, she first claims that Turnus can be the foreigner because he comes from a different city (a weak argument) but then reveals that Turnus is in fact descended from Inachus and Acrisius, that is a Mycenaean Greek $^{13}$. Amata seems to show that one can find multiple genealogical justifications for action. Indeed given the multiple layers of ethnic affiliation which Virgil met in the sources, including Cato, one might wonder if Virgil was cautioning against making too much of such arguments.

The outcome, of course, is war, and the Servian commentaries show that this is rooted in the Catonian tradition, but treated by Virgil with subtle variation. F7 can be made compatible with the other fragments if we assume that Latinus dies on Aeneas' side; the commentators have here compressed Cato's original.

F7 ( =Jordan I F11, Peter F10, Chassignet I F10, Cugusi F13)

a Serv. Aen. 4.620

(V) sed cadat ante diem mediaque inhumatus harena.

(DS+S) Cato dixit: iuxta Laurolauinium, cum

Aeneae socii praedas agerent, proelium

commissum, in quo Latinus occisus est. fugit

Turnus, et Mezenti auxilio comparator
(DS) renouauit

proelium, quo

ipse quidem uictus est ab Aenea;

Aeneas autem in ipso proelio

non comparuit.

Ascanius uero

postea Mezentium

interemit.
(S) uictus quidem est ab Aenea,

qui tamen in ipso proelio non

comparuit. Ascanius postea

Mezentium interemit.
12. Horsfall's commentary (Horsfall 2000) gives minute attention to the nuances here, such as at 263 , where « in V[irgil]'s account of Lat[inus]'s thinking, there is a leap, from gratification at working out that Aen[eas] is a descendant of Dardanus from (fairly) nearby Corythus to thinking, or hoping (273) that this is the foreign husband destined to wed his daughter" and then at 264 where the use of the word hospitio shows how «Latinus views the future solidly in the language of Roman public life."

13. Virg. Aen. 7.365-72. 
b Serv. Aen. 9.745-6

(V) ... uolnus Saturnia Iuno detorsit ueniens...

(DS+S) plerique, sed non idonei commentatores, dicunt hoc loco occisum Turnum, sed causa oeconomiae gloriam a poeta Aeneae seruatam: quod falsum est. si ueritatem historiae requiras, primo proelio interemptus Latinus est (in arce DS). inde ubi Turnus Aenean uidit superiorem, Mezenti implorauit auxilium. secundo proelio Turnus occisus est et nihilo minus Aeneas postea non comparuit. tertio proelio Mezentium occidit Ascanius. hoc Liuius dicit et Cato in originibus.

Laurolavinium is a commentator's invention, but the disappearance of Aeneas was it seems in Cato's text, and thus shows the antiquity of the tradition; Lavinium will therefore be associated with the disappearance of Aeneas, and much has been made of how to fit this story to the complex archaeology at the site, including the famous tumulus tomb ${ }^{14}$.

It is also interesting to see the way in which the appearance of Mezentius is motivated. Virgil was perhaps the first to have Mezentius flee to Turnus, rather than the other way around, and to die before Turnus. In other accounts, Mezentius and Aeneas do not meet, and Mezentius is not always killed. Virgil has transformed the story completely ${ }^{15}$. However, Macrobius, in a passage based on another fragment of Cato, explains why Mezentius is a contemptor divom; the description arose from his direction of the Latins' first fruits to himself instead of the gods ${ }^{16}$. One wonders therefore whether the contrast between the more selfless and god-fearing Aeneas and Mezentius may already have been strongly pointed in Cato's Origines.

Finally we turn to Ascanius, Aeneas' son. If we accept that the $O G R$ has correctly transmitted Cato's words, it was already claimed that Ascanius / Iulus was the originator of the Julian clan ${ }^{17}$. As it

14. The bibliography here is enormous; see the two exhibition catalogues Enea nel Lazio (1981) and Roma: Romolo, Remo e la fondazione della città (2000), and above at n. 9.

15. Eden 1965; Glenn 1971; Gotoff 1981; Kronenberg 2005 focus on Virgil; Musti 1987; Briquel 1995, 2011, 2014 and Di Fazio 2005; forthcoming look at potential realities behind the story as well. For Lavinium see Torelli 1984.

16. Macr. 3.5.10= F9.

17. See Badian 2009. turns out, he behaves well towards his stepmother, and is brave. However his lineage is complicated.

**F8 ( =Peter F1 1, Chassignet I F11, Cugusi F14)

a Serv. Aen. 6.760

(V) ille, uides, pura iuuenis qui nititur hasta ... (DS+S) Aeneas, ut Cato dicit, simul ac uenit ad Italiam, Lauiniam accepit uxorem. propter quod Turnus iratus, tam in Latinum quam in Aenean bella suscepit a Mezentio impetratis auxiliis (quod et ipse ostendit dicens 'se satis ambobus Teucrisque uenire Latinisque'); sed, ut supra diximus, primo bello periit Latinus, secundo pariter Turnus et Aeneas, postea Mezentium interemit Ascanius et Laurolauinium tenuit. cuius Lauinia timens insidias, grauida confugit ad siluas et latuit in casa pastoris Tyrrhi (ad quod adludens ait 'Tyrrhusque pater, cui regia parent armenta') et illic enixa est Siluium. sed cum Ascanius flagraret inuidia, euocauit nouercam et ei concessit Laurolauinium, sibi uero Albam constituit. qui quoniam sine liberis periit, Siluio, qui et ipse Ascanius dictus est, suum reliquit imperium: unde apud Liuium est error, qui Ascanius Albam condiderit. postea Albani omnes reges Siluii dicti sunt ab huius nomine.

b Mythogr. Vatic. prim. 2.100.10-15, p. 110 Zorzetti/Berlioz

item aliter. (11) idem Aeneas, ut Cato dicit, postquam Lauiniam, Latini regis filiam, accepit uxorem uiuente marito Turno, idem Turnus iratus tam in Latinum quam in Aeneam bella suscepit, a Maxentio impetratis auxiliis; in quorum primo bello periit Latinus, in secundo pariter et Aeneas.(12) postea Maxentium interemit Ascanius et Laurolauinium tenuit. (13) cuius Lauinia timens insidias, grauida confugit in siluas et latuit in casa pastoris Tyri - ad quam alludens 'Tyrus pater': recepit eam et fouit - et illic enixa est Siluium. (14) sed cum Ascanius flagraret inuidia, euocauit nouercam et ei concessit Laurolauinium; sibi uero Albam constituit. (15) qui quoniam sine liberis periit, Silu<i $>0$, qui et ipse Ascanius dictus est, suum reliquit imperium

Here the most salient point for us is how Cato seems to have married two traditions, one emphasising the Trojan descent and the other a more Latin one. Aeneas has two sons, one by Creusa and one by Lavinia; the first founds Alba Longa, the other founds the dynasty, and what is critical is that Cato thus makes the argument that the Roman people 
were the product of a union between the Trojans and the indigenous people, as Servius points out in his commentary on Virgil Aen. 1.6 which is our Cato F 63 (see below).

Cato, to sum up, saw the Aborigines as early Greek settlers, and may have implied that they were somewhat less well organised than the Trojans. In the OGR cited above, Latinus is about to commence battle with the Trojans when he sees how well drawn up and armed they are, but how his own troops have only sticks and stones. Although there is a personal cost, it is the amalgamation of the Aborigines and the Trojans, against the Rutulians, but eventually one assumes with them, which produces the successful Latins. So there seems to be a very strong message here about collaboration and assimilation.

\section{CATO AND THE ITALIANS}

The next section of citations relates to the Italians more generally, and here we see ways in which Servius found Cato useful to explicate Virgil, and hints that Virgil had himself used Cato, or at least sources dependent on Cato. We begin with the story of Camilla ${ }^{18}$. As Morello has shown, Camilla is a very striking figure in the epic - a highly successful warrior, who blazes a trail of unremitting destruction, and one whom the commentators do not vilify or romanticise. Her ending is motivated by a fairly Homeric lust for spoils - in this case what Morello nicely translates as the "psychedelic embroidered trouser outfit of indigo and purple, with a saffron-yellow cloak, and accessorized with Gortynian arrows and a gold quiver and helmet». But before this sad ending, in her aristeia she deals with a Ligurian who tries to trick her; he challenges her to combat on foot, but when she dismounts, he tries to flee in his chariot. She chases and kills him. The warrior is described as follows by Virgil, with attendant commentary.

18. Horsfall 1988 for the argument that Virgil invented Camilla; cf. Scarcia 2004; Morello 2008. De Luigi 2000 for an optimistic attempt to find Camilla through the Volscians of Satricum, and in the Satricum temple decorations.
F34 ( =Jordan II F1, Peter F31-2, Chassignet II F1-2, Cugusi F34-5)

a Serv. Aen. 11.700-1

(V) ... bellator filius Auni,

haud Ligurum extremus, dum fallere fata sinebant.

(DS+S) Ligures autem omnes fallaces sunt, sicut ait Cato in secundo originum

libro.

b Serv. Aen. 11.715-7

(V) uane Ligus frustraque animis elate superbis, nequiquam patrias temptasti lubricus artes, nec fraus te incolumem fallaci perferet Auno.

(DS) ... Cato originum cum de Liguribus loqueretur: sed ipsi, unde oriundi sunt, exacta memoria, inliterati mendacesque sunt et uera minus meminere.

So the commentary brings to bear the renowned deceitfulness of the Ligurians to explain Virgil's double-edged comment - among lying Ligurians, this one was conspicuous. Although the lying Ligurians may have been sufficiently commonplace as not to require direct Virgilian knowledge of the Catonian passage, in the context of the broader sense of what is known about the past, and the importance yet impossibility of accuracy, the Catonian context is intriguing. It appears that Cato was deeply offended by the fact that the Ligurians did not know their past and did not have any written records (inliterati). Cato knew the Ligurians, since he had sailed along the coast on his way to Spain as consul in 195 BC. His various accounts of events supplied Livy with relevant information. He even took up their cause in the prosecution of Q. Minucius Thermus, or perhaps it would be better to say that he used them in order to attack a magistrate who, in scourging some of their officials and killing others, had acted outrageously ${ }^{19}$.

It is the fact that they could not remember their beginnings, and had no writings, which

19. Livy 34.8.4-7 with Briscoe 1981 ad loc.; Cato ORF 59-63 Malc.; and FRHist 2.81 and 152-153 for the argument that Livy did use Cato. 
offended the historian of origins. So it is intriguing that, in a sequence where Virgil mentions the otherwise unknown but named Euneus of Clytius, Liris, Chromis, Ornytus, and an awkward Butes, amongst some recondite individuals recovered only with difficulty, the Appenninicolae bellator filius Auni, haud Ligurum extremus, is not named. So Virgil has taken Cato's accusation of ethnic ignorance, forgetfulness and mendacity, and transformed it into the fitting fate of a liar who remains nameless ${ }^{20}$.

The next passage refers to the Sabines and specifically in the context of the rape of the Sabine women. The conflict is alluded to on the shield of Aeneas in Virgil's eighth book.

**F51 ( =Jordan I F7, Peter F51, Chassignet II F22, Cugusi F59) = Gellius 14 F20; cf. Hyginus 63 F9

Serv. Aen. 8.637-8

(V) . . nouum consurgere bellum

Romulidis Tatioque seni Curibusque seueris. (DS) aut 'seueris' disciplina, aut rem hoc uerbo reconditam dixit, quia Sabini a Lacedaemoniis originem ducunt, ut Hyginus ait . . . Cato autem et Gellius a Sabo Lacedaemonio trahere eos originem referunt. porro Lacedaemonios durissimos fuisse omnis lectio docet. Sabinorum etiam mores populum Romanum secutum idem Cato dicit: merito ergo 'seueris', qui et a duris parentibus orti sunt, et quorum disciplinam uictores Romani in multis secuti sunt.

The Shield of Aeneas is interesting for the number of internal as well as external wars which are represented, and Virgil's use of the adjective severis describing Cures, which here is synonymous for the Sabines, did not need any detailed knowledge of Cato, nor is there any evidence of a direct reference to Cato. Servius is demonstrating his learning by picking out the Spartan ancestry which he found in Cato and the historian Gellius. However, there has been a substantial debate about what Cato's original might have included, and it is conceivable that Cato's version was similar to that of Dionysius of Halicarnassus (2.49.5), quoting

20. On the other named individuals see Horsfall 2003. On line 700 , Horsfall suggests, contrary to this reading, that « his namelessness might well be taken as a further indication that bits of Bk. 11 were composed in haste and without much further revision. " local histories, that a colony of Spartans joined some indigenous Sabines, or at least that Cato included the story alongside the stronger version that the Sabines were entirely descended from the Spartans ${ }^{21}$.

The next lines of Virgil are therefore interesting, in which he shows the battle resolved and the two kings making peace before the altar of Zeus, in armour, holding paterae and simultaneously sticking a pig. As Kuttner pointed out, the armed sacrifice was particularly appropriate to the performance of a foedus or coniuratio ${ }^{22}$. This is usually thought to be an Italic custom, so Virgil may be emphasising the Italic rather than the Greek side of Sabine identity at this point. It is also interesting that Servius claims another meaning for the severe Sabines - of all those peoples whose women were seized by Romulus, only the Sabines took up arms. We cannot easily refer this back to Cato given the state of the evidence, but perhaps one can say that for Virgil at any rate, the combination of the determined opposition and then the secured peace perhaps represented as an outcome a stronger and more vital shared project. In this way, Virgil may well reflect the Catonian spirit, as well as offering an interesting sidelong glance at the outcome of more recent and bitterly fought civil wars ${ }^{23}$.

21. See FRHist 14 Gellius F20; FRHist 2.96-98; Letta 1984; 2008 for an argument that Cato was specifically arguing against the Greek origin.

22. On the armed sacrifice see Kleiner 1983 and Kuttner 1995 , p. 124-125, noting also that DS cites a statue of the scene on the Via Sacra near the foot of the Capitoline Hill and by the temple of Jupiter Stator (Aen. 8.641) (huius autem facti in sacra via signa stant, Romulus a parte Palatii, Tatius venientibus a rostris). On this statue see Coarelli 1983, p. 52; LTUR s.v. Signa Romuli et Titi Tatii. This should not be conflated with the statues of Romulus and Titus Tatius mentioned by Asconius p. 29C and Pliny NH 34.23 as sine tunica (which Gellius NA 6.12.3 notes is an early version of Roman dress). Our statue may have given rise to representations such as the two gold staters RRC 28.1, 29.1 from 225 to 212 BC, and the anomalous denarius of $137 \mathrm{BC}, R R C 234$, which might suggest the statue was relatively early. As a concept, it presumably also influenced the representations on coins of several warriors (the number varies between two, four and eight) sticking a pig, which were put out by the antiRoman parties in the Social War; see $H N$ 408, 411, 413, $415,423,425,428$.

23. See Bruggisser 1987, p. 203-207 on this passage, and also 255-256 where he suggests that the Sabine aggression turned their action into an iniustum bellum, thereby saving the reputation of Romulus. Bruggisser also argues that the effective early dyarchy of Romulus and Remus prefigured 
Although Cesare Letta has powerfully argued for Cato's downplaying of the Greek contribution to Italy, in at least one instance, we see Cato doing something slightly more complex. The issue at stake is who exactly were the Latins, or better, when they came into being.

*F63 ( =Jordan I F5, Peter F5, Chassignet I F6, Cugusi F6)

Serv. Aen. 1.6

(V) ... genus unde Latinum ...

(DS+S) . . . Cato in originibus hoc dicit, cuius

auctoritatem Sallustius sequitur in bello Catilinae,

primo Italiam tenuisse quosdam qui appellabantur Aborigines. hos postea aduentu Aeneae Phrygibus iunctos Latinos uno nomine nuncupatos.

Virgil calls the peoples whom Aeneas meets Latins right from the beginning, but strictly speaking, according to Cato, the Latins were the product of the union of the two. This is also clear from F8 above. It is not wholly surprising that Virgil should have taken a more direct route - as Servius notes at 7.181 the word "Aborigines" will not scan, so his paraphrase there aliique ab origine reges is a clever hint. Cato's message of union and assimilation is clear. In a way, Virgil turns it on its head. Cato has primitive Greeks meeting civilized Trojans and producing decent Latins (with the Sabines helping add a little austerity). Virgil has conflicted but powerful Trojans meeting civilized but disordered Latins, and according to Juno's final deal, being absorbed. In both the mixture makes the resulting people stronger, but Virgil's version perhaps better reflects the Augustan tota Italia ${ }^{24}$.

that of Honorius and Arcadius and that this gave the lie to the Christian accusations against the Romans. For an influential reading of the Sabines in their Greek, Roman and local contexts see Dench 1995, and recently Mastrorosa 2004, Benelli 2014.

24. Barchiesi 2008. See Russo 2010 on pre-Augustan presentations of Roman and Italic affinity, and Ando 2002 on variations in the way Italy could be presented even during the Augustan period. Ando argues that Cato could have had no concept of the unification of Italy, and I would emphasise that my reading depends only on seeing the impact of local partnerships, not a single Italy. On that theme, see, amidst an infinite bibliography, Pobjoy 2000, Dench 2005, p. 152-221 ; Bourdin 2012, p. 778-785. Gildenhard 2007 , p. 82 sees this sequentially; Cato described the ethnic components of the Roman people; Ennius was
Other citations reflect the persistent aetiological thinking of the ancients on city foundations.

F64 ( =Jordan III F3, Peter F70, Chassignet III F3, Cugusi F75)

cf Coelius 15 F57

Serv. Aen. 3.401-2

(V) ... hic illa ducis Meliboei parua Philoctetae subnixa Petelia muro.

(DS) multi ita intellegunt: non 'Philoctetae Petelia', sed 'Philoctetae muro'; nam ait Cato a Philocteta, condita iam pridem ciuitate, murum tantum factum

This is a perfect example of how Virgil's choice of story is deliberate, but leaves open learned reference to alternatives, which the commentators were alive to. There were two versions of the origins of Petelia; one has it as a foundation of Philoctetes; the other, which is in Cato, suggests that Philoctetes merely added a wall. The first may come from Timaeus, the second may relate to Petelia's refusal - unlike other Greek neighbours - to submit to Hannibal in 216-15 BC. For Virgil, Petelia's Greekness is helpful because Aeneas is relating Helenus' directions, and telling him to avoid an area where cuncta malis habitantur moenia Graeis, but he leaves sufficient ambiguity to hint at the alternatives.

This erudite and detailed section of the Aeneid probably owes a lot to, and in some sense may rather imitate, the scholarly accounts of Cato and others ${ }^{25}$. It is interesting that Helenus also instructs Aeneas in the practice of sacrificing with a veiled head ${ }^{26}$. So we have a rather intriguing and complex passage here, where geography, ethnog-

interested in Rome as « a res publica held together by legal ties, communal values and public institutions; it is only with Virgil that the idiom of race, blood-descent and crossbreeding enters the genre [sc. of epic] in full force."

25. On this sort of geographical erudition, see Musti 1988; Thomas 1982; Traina 1993-1994; Ando 2002; more broadly, Skempis-Ziogas 2013.

26. Cf. Lucr. 5.1198-9. Festus p. 434 L s.v. Saturnia on Aeneas covering his head so as not to be interrupted by Ulysses while sacrificing to Venus. As Horsfall says, the Trojans act like Romans now, but will not gain Juno's goodwill for many years to come, and are in hiding from the wicked Greeks; "the reconciliations with Greece and Rome are interwoven" (Horsfall 2006), p. 306. For the custom, which would become part of the cinctus Gabinus, see sources gathered at ibid. 158 . 
raphy, mythology (Scylla and Charybdis follow) and the difficult challenge of winning over Juno are all combined. ${ }^{27}$

There are a number of instances where Servius cites Cato in the context of Virgil's descriptions of Italian cities in Book 5. All three parties can be seen to be demonstrating immense learning.

F65 ( =Jordan II F26, Peter F54, Chassignet II F24, Cugusi F55)

Serv. Aen. 5.563-5

(V) una acies iuuenum, ducit quam paruus ouantem nomen aui referens Priamus, tua clara, Polite, progenies, auctura Italos ...

(S) illum dicit quem supra a Pyrrho introduxit occisum; de quo Cato in originibus dicit quod ad Italiam uenerit et segregatus ab Aenea condiderit oppidum Politorium a suo nomine.

The derivation of the name of the town Politorium from the Trojan Polites was clearly in Cato and may have been even older. Virgil deftly refers to this without actually mentioning the town. The reader was assumed to be able to spot the connection.

*F66 ( =Jordan I F18, Peter F18, Chassignet I F18, Cugusi F21)

a Serv. Aen. 5.755

(V) PY>interea Aeneas urbem designat aratro (DS+S) quem Cato in originibus dicit morem fuisse.

(DS) condituri enim

(S) conditores enim ciuitates ciuitatis

taurum in dextera, uaccam in

taurum in dexteram, uaccam

sinistra iungebant, et intrinsecus iungebant, et cincti ritu

Gabino, incincti ritu Sabino,

(DS+S) id est togae parte caput uelati, parte succincti, tenebant stiuam incuruam (obliquam DS), ut glebae omnes intrinsecus caderent, et ita sulco ducto loca murorum designabant (designabant murorum DS), aratrum suspendentes circa loca portarum. b Isid. orig. 15.2.3

locus enim futurae ciuitatis sulco designabatur, id est aratro. Cato qui urbem, inquit, nouam condet, tauro et uacca aret; ubi arauerit, murum faciat; ubi portam uult esse, aratrum sustollat et portet, et portam uocet.

These important passages show the way the Romans founded cities - or at least consistently thought that they had founded cities. (The suggestion that this was a Sabine not a Gabine rite is an error in the manuscripts). On the face of it there is no reason to assume that any particular reference to Cato is necessary, because the custom was very well known. However, again, Virgil may be doing more here. In context, Aeneas founds Segesta as a mixed Trojan and Sicilian foundation, using a rite he will use again to found Troia in Latium (7.157). He designates part of the city Ilium and part Troia. The kingship is taken by Troianus Acestes, who was himself the son of Egesta, who had been sent away from Troy by her father in fear of Laomedon, and the local Sicilian river god Crinisus ${ }^{28}$. Acestes is himself therefore the product of the union of Troy and Sicily. The claim for the closeness of the link between Segesta and Rome via Aeneas is found in Cicero's prosecution of Verres, and it has been argued that it contributed to the choice by Segesta of Rome over Carthage in the First Punic War. The only direct evidence for this is in Zonaras ${ }^{29}$. However, Virgil strongly supports the connection, by linking the foundation rite of Segesta directly to the foundation rite of Troia, foreshadowing the foundation rite of Rome. Coming not long after the grim ending of Book 4, and the seeds of hatred between Carthage and Rome, an attentive reader might have drawn obvious conclusions. Notice also how relatively peaceful this foundation is the women want to stay, they are not seized, and Acestes and Aeneas participate joyfully and co-operatively. There is no reason to think that Cato contributed anything to this picture; rather we see here another model of how to create a city, and one characterised by a congruence of wills.

28. Serv. Aen. 1.550.

29. Cic. Verr. 4.72; 5.83; 5.125; Zonar. 8.9 (summarising Cassius Dio). For a careful account, with reference to previous bibliography, see Prag 2010. 
The catalogues in Aeneid 7 and 10 clearly owed much to Cato, and also to Varro. This has been well discussed by Coarelli, and we can pass rapidly through these fragments ${ }^{30}$.

F68 ( =Jordan II F23, Peter F60, Chassignet II F30, Cugusi F66)

Serv. Aen. 7.681-4

(V) ... hunc legio late comitatur agrestis :

quique altum Praeneste uiri quique arua Gabinae

Iunonis . . .

... colunt ...

(DS) Cato dicit: quia is locus montibus praestet,

Praeneste oppido nomen

dedit. ergo 'altum', quia in montibus locatum.

We know Cato also reported the story of Caeculus at Praeneste (F67), giving an account of him as the son of Vulcan, found in a hearth, who brought a haphazard collection of shepherds together to found a city, thus mirroring elements of the Romulus and Remus story. Here we see Virgil picking up and playing on Cato's etymology that Praeneste praestet, by calling it altum (high). Readers presumably derived even greater pleasure if they could pick up these hints ${ }^{31}$.

F69 ( =Jordan II F17, Peter F48, Chassignet II F19, Cugusi F52)

Serv. Aen. 7.697

(V) et Cimini cum monte lacum lucosque Capenos. (DS) hos dicit Cato Veientum <iuuenes> condidisse auxilio regis Properti, qui eos Capenam cum adoleuissent miserat.

Cato claims that Capena is founded by a ver sacrum from Veii - and yet this is odd in many respects. Veii has a king with an Umbrian name and the ver sacrum is usually Sabine. It is not clear why the Servian commentary picked this up, and it has no bearing on Virgil, but it reminds us of how Cato can surprise us.

30. Coarelli 2004.

31. For Virgil's learned etymologies of names see O'Hara 1996.
F70 ( =Jordan II F13, Peter F45, Chassignet II F15, Cugusi F49)

Serv. Aen. 10.179-80

(V) hos parere iubent Alpheae ab origine Pisae, urbs Etrusca solo ...

(DS) Cato originum qui Pisas tenuerint ante aduentum Etruscorum, negat sibi compertum; sed inueniri Tarchonem, Tyrrheno oriundum, postquam +eurundem sermonem ceperit + , Pisas condidisse, cum ante regionem eandem Teutones quidam, Graece loquentes, possederint.

Similarly Cato is unusual in seeing Pisa as an Etruscan foundation, rather than a pre-existing one to which a bewildering variety of potential founders was attributed ${ }^{32}$. Servius notes that Virgil has cleverly used an adjective, Alphea, which relates to the river next to the Arcadian city of Pisa; and Virgil also hints at Aborigines ( $a b$ origine). So Virgil manages to hint at both a complex tradition of pre-existing non-city foundations and Cato's Etruscan foundation ${ }^{33}$.

F71 ( =Jordan II F20, Peter F46, Chassignet II F17, Cugusi F50)

Serv. Aen. 10.184

(V) et Pyrgi ueteres intempestaeque Grauiscae. (DS+S) 'intempestas' ergo 'Grauiscas' accipimus 'pestilentes' secundum Plinium in naturali historia et Catonem in originibus, ut intempestas intellegas sine temperie, id est tranquillitate: nam ut ait Cato, ideo Grauiscae dictae sunt, quod grauem aerem sustinent.

Here both Cato and Virgil found different ways to refer to the unhealthy atmosphere of Gravisca, Cato via a direct etymology (Graviscae gravis), and then Virgil glossing that with the word intempestus, which can mean both stormy and unhealthy ${ }^{34}$.

32. See Bruni 1998, p. 35-36, 57, 62-64.

33. Santini $2004 ; 2008$ for other examples of how the commentary tradition brings out the depth of Virgil's knowledge of the Etruscans.

34. For a collection of ancient sources on Gravisca see Fiorini 2005, p. 19-22. The Plinian passage is not identifiable. On the archaeology of Gravisca see the recent exhibition catalogue, Il Mare che univa 2014. 
F72 ( =Jordan II F14, Peter F62, Chassignet I F13, Cugusi F67)

Serv. Aen. 11.567-8

(V) non illum tectis ullae, non moenibus urbes accepere ...

(DS+S) non mirum a nulla hunc ciuitate susceptum; nam licet Priuernas esset, tamen quia in Tuscorum iure paene omnis Italia fuerat, generaliter in Metabum omnium odia ferebantur. nam pulsus fuerat a gente Volscorum, quae etiam ipsa Etruscorum potestate regebatur: quod Cato plenissime exsecutus est.

In this citation, the major issue is whether we should look to Cato for a substantial account of Metabus $^{35}$. We have suggested instead that Cato is being used by Servius as the source for the extent of Etruscan domination in Italy, and its rejection by the Volscians. That is, Servius recognised that Metabus was thrown out by the Volscians because he was an Etruscan ruler. This is interesting for two reasons; first it implies that Servius, or his predecessors, were using Cato not simply for stories but also for historical explanation; and second that we have no warrant for assuming that Cato was telling a romanticised story.

The remainder of the fragments are largely cited for grammatical reasons ${ }^{36}$. Many of the passages which we have seen are well-known, and the reconsideration in the new edition of the fragments has not dramatically changed interpretation, but has encouraged us to be aware of the limitations of our knowledge. The edition has also made us acutely aware of the significant role which the citing authority has in shaping the fragmentary tradition.

\section{SERVIUS ON CATO}

Naturally, one would not wish to assume that the only debt Virgil owed to Cato was in the passages

35. Metabus is Camilla's father; for Servius and Camilla see Morello 2008 and above, but Cato comes in only tangentially there and obviously gives no warrant to assuming that he referred to her story, or that it was older than Virgil himself. The case for Virgilian invention is made by Horsfall 1988. On the Volsci, see Quilici-Quilici Gigli 1997; Quilici Gigli 2004; Musti 1992 for the sources; for a recent debate, Aberson et al. 2014, p. 245-277 (Di Fazio and Gnade).

36. F12, F62, F73, F84b, F119b, F123, F124, F125, F144, F145, F146, F147, F148, F149, F150. cited here; in fact here may be many other occasions on which Cato lies behind a line of Virgil or an interpretation. Conversely, in many instances, as we have seen, and is even more apparent from the purely grammatical fragments, it is likely that the passages cited had very little bearing on Virgil at all, and the only reason they are brought in is because of the commentators' views.

F119 is an example where the views of the commentator seem to have intruded. Here I have given the full passage from the Servian commentary, not just the Catonian section.

F119 ( =Jordan VII F9, Peter F114, Chassignet VII F10, Cugusi F129)

a Charis. 128

nam Cato in originibus mulieres, inquit, nostrae capillum cinere unguitabant, ut rutilus esset crinis.

\section{b Seru. Aen. 4.698-9}

(V) nondum illi flauum Proserpine uertice crinem abstulerat ...

(S) FLAVUM CRINEM matronis numquam flaua coma dabatur, sed nigra: unde Iuvenalis 'et nigro flavum crinem abscondente galero'. Huic ergo dat quasi turpi : (DS) uel quia in Catone legitur de matronarum crinibus : flauo cinere unctitabant ut rutili essent. rutili Thilo: rutuli $\mathrm{T}$ : rutile $\mathrm{F}$

Servius has been thought to have been somewhat harsh on Dido, but this passage is not usually brought to bear ${ }^{37}$. The question is, why is Dido a blonde? It is surprising that in the context of a passage normally regarded as of exceptional beauty, the release of the spirit of Dido in her tormented death, such a sharp note should be struck. Dido is compared by Servius to Messallina on her way to slake her sexual desire with a gladiator in Juvenal 6.120, or, in DS, with luxurious Roman matrons. It is also interesting that DS perhaps also Donatus? - seems to have muddled the referent - Cato, at least in Servius, but not in Charisius, talks about the ash being flavum and the hair rutilus. It looks difficult to make any sense of

\footnotetext{
37. Rudd 1976. Sharrock 2008 finds a more complex reading, and shows that one should not try to construct a neat opposition between Christian and pagan readings.
} 
this as having any bearing at all on the passage; it is almost as if Servius Danielis has remembered the Charisius citation more than the Cato passage, or else Donatus had something a lot cleverer.

One does slightly wonder whether the gloss rather counts against Dido. Pease collects a mass of passages to show that blondness was attractive $^{38}$, but here it looks like artificiality, as though the censorious commentator could not permit the suicidal queen to depart without a hint of condemnation, and one which one might have to dig hard for in Virgil's own poem.

\section{SOME CONCLUSIONS}

The Servian commentary knew when to turn to Cato the Elder. The catalogues and the early origin stories were the natural places where Cato could be useful. Servius is simplifying quite a lot, and we would be the poorer without Servius Danielis and the additional material, presumably from Donatus, which is added in the $7^{\text {th }}$ or $8^{\text {th }}$ century, and hints at an even richer tradition, although Pellizzari still thinks that most of the material was taken from excerpts ${ }^{39}$.

It is clear that this exercise however can only touch on how deep the knowledge of Cato was, and indeed how first hand. Even for the most extensive citations the material was sufficiently well-known for it potentially to have come down via intermediate sources. However it is also evident, as one would expect, that the bulk of attention was on the early history, and indeed the bulk of the fragments where book numbers are known come from Book 1. Yet the organization of the Origines remains problematic. Book 1 deals with early Rome, but we can see that Book 1 also discussed Alba Longa, Capena, the Aborigines and the land of the Volsci, Tusculum and Antemnae, so it was more wide-ranging.

It looks rather as if the term Origines was itself a problem, as is implied in a passage of Festus $(216 \mathrm{~L}$ our T7) :

originum libros quod inscripsit Cato non satis plenum titulum propositi sui uidetur amplexus, quando praegrauant ea quae sunt rerum gestarum populi Romani.

38. Pease 1935, p. 471-473 at Virg. Aen. 4.590.

39. Pellizzari 2003, p. 224.
Now the res gestae populi Romani are for the most part wars, and that may be the best way into the Origines - not through the foundation stories, but through the fact of the Roman conquest of the peninsula of Italy ${ }^{40}$. It seems likely that the first book took the Roman conquest to the beginning of the Republic; the next two ran through the origins of states, perhaps organised by their moment of conquest; before arriving at more modern times.

The close connection between origines and res gestae comes across clearly in two Virgilian passages where the word origo is used; first Aeneas to Venus in Book 1.372-4 says that it would take all day to go through everything from the beginning - ab origine - he even talks about the annalis nostrorum laborum. Early in Book 7, the second half of the Aeneid, it is in Latinus' palace where we see the kings ab origine (as we have seen, a hint at Aborigines), and the heroes of wars. (The same focus on wars can be seen on the Shield of Aeneas).

This may help explain why Servius can use Cato as evidence for a period of Etruscan domination (above on F72); this presumably is one of the cycles of dominance. It also means that it is not necessary to believe that Cato had to deny all eastern influence in Italy, as Letta argued. ${ }^{41}$ It seems clear that he was comfortable with the idea that the Aborigines came from the east, and that there was a Trojan and a Greek presence from early times. But he thought that there were other stories too, and was cross when he was unable to discover them. What seems most evident is his interest in the combinations of peoples which made up Italy.

This leaves Virgil. There are a few instances where the evidence of Servius permits us to see what Virgil has done with his source material, and

40. This is on the face of it at odds with the suggestion by Brunt 1988, p. 117 that Cato downplayed wars with the Italians and preferred to concentrate on wars which they fought together, which he based on the idea that the first three books were on origins and Book 4 began with the first Punic War. We have preferred a view closer to that of Williams 2001, p. 48-58 on North Italy, that Cato was interested in areas that were under Roman sway at his time, and in explaining how that had happened. We may reconcile the views if we believe that Cato was interested in the product of conscious combination, whether peacefully achieved or not, and that Books 4-7 celebrate the achievements of the particular amalgam of peoples which he had previously described.

41. Letta 1984; 2008; FRHist 1.210-11, and, elegantly, Musti 1988, p. 255. 
it is usually, and unsurprisingly, clever. As Henry James once said of Gustave Flaubert, one senses that there were « libraries of books behind his most innocent sentences ${ }^{42}$. I think however that we do learn something about the difference between Cato and Virgil. Virgil romanticises the politics, and brings to bear an immensely subtle characterization, which we can occasionally see also in Livy, but not as far as one can tell in Cato. We already see in Cato the determined rationalization of history.

My final observation is that the overwhelming presence of Cato the Elder in the Servian commentaries is an interesting reflection on the tradition but also an interesting problem for editors of Cato. Servius is the third most important citing authority by volume (after Nonius and Aulus Gellius) and Cato is by far the most cited author. 38 out of 156 fragments of Cato come from Servius or Servius Danielis - 25\% in other words - and another 25\% from Charisius, Priscus and Nonius Marcellinus.

The Servian contribution would be substantially reduced were it not for the need to explain the two Virgilian catalogues, and once these authoritative statements from the earliest relevant source had entered the commentaries, they were hard to dislodge. However, the economy of Cato's work may not be identical to the picture given by the sources. Cato was interesting as someone who had sought out early foundation stories, but there must have been a narrative context, and yet it looks as if he was less interesting to his citing sources for that narrative, which was presumably better handled by subsequent and more stylistically satisfying historians.

That may mean that Cato dealt with narrative by indicating the broad geographical devel- opment of Roman rule, and we know he was less interested in individual feats of glory. For Virgil then, Cato was an interesting source, because he dealt with early Rome, perforce, and with ethnic identities, and for others, he was interesting because he wrote in a relatively early form of Latin. It does not follow either that Cato did not give a clear historical narrative, or that other sources did not give such a narrative. Neither Cato's narrative, nor that of the other sources, was particularly interesting to the citing sources we have. One cannot use the surviving fragments of Cato to argue for a large difference in scale of treatment between early Roman history and early Republican history.

Cato's rather peculiar way of doing history was - ironically - perfectly attuned to the Hellenistic mythography of someone like Lycophron, and worked well with Timaeus' interests in the relations between east and west ${ }^{43}$. Whilst he downplays the Greek contribution, he does not elide it altogether, and he clearly accepted the Trojan myth and values it. There was thus a blueprint for Virgil's mixed and mixed up Italy, one which could embrace the diversity of the country. The second half of Virgil's Aeneid is a profoundly Italic work; it confronts the coming power of Rome with the enormous variety of pre-Roman Italy, and by implication has things to say about the value of that world, which, one could argue, is both defended by Augustus and crushed by Rome. If Cato's message was actually closer to a defence of the value of the mixing of populations than a rejection of the foreign, then stern Cato was perhaps a more obvious model for neoteric Virgil than one might at first have imagined ${ }^{44}$. 


\section{Bibliography}

Aberson et al. R $2014=$ M. Aberson, M.C. Biella, M. Di Fazio, M. Wullschleger (ed.), Entre archéologie et Histoire: dialogues sur divers peuples de l'Italie préromaine, Études Genevoises sur l'Antiquité, 2, Bern, 2014.

Ando 2002 = C. Ando, Vergil's Italy: Ethnography and Politics In First-Century Rome, in D.S. Levene, D. Nelis (ed.), Clio and the poets: Augustan poetry and the traditions of ancient historiography, Leiden, p. 123-142.

Badian 2009 = E. Badian, From the Iulii to Caesar, in M. Griffin (ed.), A Companion to Caesar, Malden, p. 1122.

Barchiesi 2006 = A. Barchiesi, Mobilità e religione nell'Eneide. Diaspora, culto, spazio, identità locali, in D. Elm von der Osten, J. Rüpke, K. Waldner (ed.), Texte als Medium und Reflexion von Religion im römischen Reich, Stuttgart, p. 13-30.

Barchiesi $2008=$ A. Barchiesi, Bellum Italicum. L'unificazione dell'Italia nell'Eneide, in G. Urso (ed.), Patria diversis gentibus una? Unita politica e identità etniche nell'Italia antica. Atti del convegno internazionale, Cividale del Friuli, 20-22 settembre 2007, Milan, p. 24360.

Baron 2013 = C. A. Baron, Timaeus of Tauromenium and Hellenistic Historiography, Cambridge, 2013.

Benelli 2014 = E. Benelli, I Sabini. Prospettiva archeologica, in Aberson et al. 2014, p. 137-148.

Bourdin 2012 = S. Bourdin, Les peuples de l'Italie préromaine. Identités, territoires et relations inter-ethniques en Italie centrale et septentrionale (VIII ${ }^{e}-I^{e r}$ s.av. J.-C.), Rome, 2012.

Briquel $1995=\mathrm{D}$. Briquel, La fabrication d'un tyran: Mézence chez Virgile, in Bull.Ass.Budé, 2, 1995, p. 173185.

Briquel 2011 = D. Briquel, Lausus fils de Mézence et le Laucie Mezentie de l'inscription du Louvre, in D. Maras (ed.), Corollari. Scritti di antichità etrusche e italiche in omaggio all'opera di Giovanni Colonna, Pisa-Roma, 2011, p. 1418.

Briquel $2014=$ D. Briquel, La figura di Mezenzio in età romana, in Gli Etruschi e il Mediterraneo. La città di Cerveteri, catalogo della mostra (Paris-Rome 2013-2014), Paris, 2014, p. 322-323.

Briscoe $1981=\mathrm{J}$. Briscoe, A Commentary on Livy: Books $X X X I V-X X X V I I$, Oxford, 1981.

Bruggisser $1987=$ P. Bruggisser, Romulus Servianus. La légende de Romulus dans les Commentaires à Virgile de Servius: mythographie et idéologie à l'époque de la dynastie théodosienne, Bonn, 1987.

Bruni 1998 = S. Bruni, Pisa etrusca : anatomia di una città scomparsa, Milan, 1988.

Brunt $1988=$ P.A. Brunt, The Fall of the Roman Republic and Related Essays, Oxford, 1988.

Cameron 2011 = A. Cameron, The Last Pagans of Rome, Oxford, 2011.

Casali - Stok 2008 = S. Casali, F. Stok (ed.) Servio : stratificazioni esegetiche e modelli culturali / Servius: exegetical stratifications and cultural models, Brussels, 2008.
Ceccarelli - Marroni 2011 = L. Ceccarelli, E. Marroni, Repertorio del Santuari del Lazio, Rome, 2011.

Coarelli 1983 = F. Coarelli, Il foro romano, I, Rome, 1983.

Coarelli 2004 = F. Coarelli, Miti di fondazione delle città italiche in Servio, in Santoni - Stok 2004, p. 11-32.

Cooley $2000=\mathrm{A}$. Cooley, Politics and religion in the Ager Laurens, in A. Cooley (ed.), The Epigraphic Landscape of Roman Italy, London, (Bulletin of the Institute of Classical Studies Supplement 73), 2000, p. 173-191.

De Luigi 2000 = A. De Luigi, Camilla, le Amazzoni e I Volsci. Alcune osservazioni circa il significato del ciclo decorative del tetto del secondo tempio di Mater Matuta a Satricum, in Mededelingen van het Nederlands Instituut te Rome, 58, 1999, p. 221-245.

Dench 1995 = E. Dench, From Barbarians to New Men: Greek, Roman, and Modern Perceptions of Peoples of the Central Apennines, Oxford, 1995.

Dench 2005, = E. Dench, Romulus' Asylum. Roman Identities from the Age of Alexander to the Age of Hadrian, Oxford, 2005.

Di Fazio $2005=$ M. Di Fazio, Uno, nessuno e centomila Mezenzio, in Athenaeum 93, 2005, p. 51-69.

Di Fazio forthcoming = M. Di Fazio, Figures of Memory. Mezentius, Aulus Vibenna, Valerius Publicola between history and legend, in K. Sandberg, C. Smith, Omnium Annalium Monumenta.

Eden 1964-1965 = P.T. Eden, Mezentius and the Etruscans in the Aeneid, in PVS, 4, 1964-1965, p. 31-40.

Enea nel Lazio 1981 = Enea nel Lazio: archeologia e mito bimillenario virgiliano / Roma, 22 settembre-31 dicembre 1981, Campidoglio, Palazzo dei Conservatori, Rome, 1981.

$E V=$ Enciclopedia Virgiliana, Rome, 1984-1991.

Fabrizi 2012 = V. Fabrizi, Mores veteresque novosque. Rappresentazioni del passato e del presente di Roma negli Annales di Ennio, Pavia, 2012.

Feeney 1984 = D. Feeney, The Reconciliations of Juno, in CQ 34, 1984, p. 179-194.

Ferris-Hill $2011=\mathrm{J}$. L. Ferris-Hill, Virgil's program of Sabellic etymologizing and the construction of Italic identity, in TAPA 141.2, 2011, p. 265-284.

Fiorini $2005=\mathrm{L}$. Fiorini, Topografia generale e storia del santuario. Analisi dei contesti e delle stratigrafie, (Gravisca: scavi nel santuario greco 1.1), Bari, 2005.

Fowler 1997 = D. C. Fowler, The Virgil Commentary of Servius, in C. Martindale (ed.), The Cambridge Companion to Virgil, Cambridge, 1997, p. 73-78.

FRHist = T.J. Cornell et al., The Fragmentary Roman Historians, 3 vol., Oxford, 2014.

Glenn 1971 = J.M. Glenn, Mezentius and Polyphemus, in AJP 92, 1971, p. 129-155.

Glidenhard 2007 = I. Gildenhard, Virgil vs. Ennius - or: The Undoing of the Annalist, in W. Fitzgerald, E. Gowers (ed.), Ennius perennis: the Annals and beyond, Cambridge 2007, p. 73-102.

Goold $1970=$ P. Goold, Servius and the Helen episode, in HSCP 74, 1970, p. 101-168.

Gotoff $1981=$ H.C. Gotoff, The transformation of Mezentius, in TAPA 114, 1984, p. 191-218. 
Grandazzi 2010 = A. Grandazzi, Lavinium, Alba Longa, Roma: à quoi sert un paysage religieux?, in Revue de l'histoire des religions, 227.4, 2010, p. 573-590.

$H N=\mathrm{K}$. Rutter (ed.), Historia Numorum. Italy, London, 2001.

Horsfall $1987=\mathrm{N}$. Horsfall, Laurentes, in EV 3, p. 141-14.

Horsfall $1988=\mathrm{N}$. Horsfall, Camilla, o $i$ limiti dell'invenzione, in Athenaeum 66, 1988, p. 31-51.

Horsfall $2000=\mathrm{N}$. Horsfall, Virgil, Aeneid 7. A Commentary, Leiden, 2000.

Horsfall $2003=$ N. Horsfall, Virgil, Aeneid 11. A Commentary, Leiden, 2003.

Horsfall $2006=$ N. Horsfall, Virgil, Aeneid 3. A Commentary, Leiden, 2006.

Il Mare che univa $2014=$ Il mare che univa. Gravisca santuario mediterraneo. Catalogo della mostra (Civitavecchia, 20 giugno-20 luglio 2014), Civitavecchia, 2014.

James $1893=\mathrm{H}$. James, Essays in London and Elsewhere, New York, 1893.

Kaster $1988=$ R. A. Kaster, Guardians of Language. The Grammarian and Society in Late Antiquity, Berkeley, 1988.

Kleiner 1983 = F. Kleiner, The sacrifice in armor in Roman art, in Latomus 42, 1983, p. 287-302.

Kronenberg 2005 = L. Kronenberg, Mezentius the Epicurean, in TAPA 135. 2, 2005, p. 403-431.

Kuttner $1995=$ A. L. Kuttner, Dynasty and Empire in the Age of Augustus, Berkeley, 1995.

Letta 1984 = C. Letta, $L^{\prime}$ «Italia dei mores romani» nelle Origines di Catone, in Athenaeum, 72, 3-30, p. 416-439.

Letta 2008 = C. Letta, I legami tra $i$ popoli italici nelle Origines di Catone tra consapevolezza etnica e ideologica, in Urso 2008, p. 171-195.

Lloyd $1961=$ R. B. Lloyd, Republican Authors in Servius and the Scholia Danielis, in HSCP 65, 1961, p. 291-341.

LTUR = E. M. Steinby (ed.), Lexicon Topographicum Urbis Romae, Rome, 1993-2000.

Mastroiacovo 2004 = C. Mastroiacovo, Servio e il problema di Laurentum, in Santini - Stok 2004, p. 75-110.

Mastrorosa 2004 = I. Mastrorosa, I primordi Sabini in Servio fra storiografia e antiquaria, in Santini - Stok 2004, p. 235-258.

Morello $2008=$ R. Morello, Segregem eam fecit. Vergil's Camilla and the Scholiasts, in Casali - Stok 2008, p. 3857.

Musti 1987 = D. Musti, Etruria e Lazio nella tradizione (Demarato, Tarquinio, Mezenzio), in Quaderni Arch. Etrusco-italica, 15, 1987, p. 139-153.

Musti 1988 = D. Musti, Strabone e la Magna Grecia. Città e Popoli dell'italia antica, Padua, 1988.

Musti 1992 = D. Musti, L'immagine dei Volsci nella storiografia antica, in S. Quilici Gigli, I Volsci. Undicesimo incontro di studio del Comitato per l'archeologia laziale, Rome, 1992, p. 25-31.

Nonnis 1995-1996 = D. Nonnis, Un patrono dei dendrofori di Lavinium. Onori e munificenza in un dossier epigrafico di età severiana, in RendPontAcc, 68, 1995-1996, p. 235-262.

O'Hara 1996 = J.J. O'Hara, True Names. Vergil and the Alexandrian tradition of etymological wordplay, Ann Arbor, 1996.
Pease 1935 = A.S. Pease, Publi Vergili Maronis Aeneidos liber quartus, Cambridge Mass., 1935

Pellizzari 2003 = A. Pellizzari, Servio. Storia, cultura e istituzioni nell'opera di un grammatico tardoantico, Florence, 2003.

Pobjoy $2000=$ M. Pobjoy, The First Italia, in K. Lomas, E. Herring (ed.), The Emergence of State Identities in Italy in the First Millennium BC, London, 2000, p. 187-211.

Poccetti 2004 = P. Poccetti, Servio come fonte di documentazioni linguistiche e etnografiche dell'Italia antica tra tradizioni indigene e filtri alloglotti, in Santini - Stok 2004, p. 259-306.

Prag $2010=$ J. Prag, Kinship diplomacy between Sicily and Rome, in D. Bonanno, C. Bonnet, N. Cusumano, S. Péré-Noguès (ed.), Alleanze e parentele. Le "affinità elettive» nella storiografia sulla Sicilia antica. Convegno internazionale, Palermo 14-15 aprile 2010, Caltanissetta, 2011 , p. 179-206.

Quilici - Quilici Gigli 1997 = S. Quilici-Gigli, L. Quilici, (ed.), I Volsc i: testimonianze e leggende, Rome, 1997.

Quilici Gigli 2004 = S. Quilici Gigli, Circumfuso volitabant milite Volsci. Dinamiche insediative nella zona pontina, in S. Quilici Gigli, L. Quilici (ed.), Viabilità e insediamenti nell'Italia antica (ATTA 13), Rome, 2004, p. 235-275.

Ramires 2004 = G. Ramires, Riflessioni sulle fonte storiografiche dei Commentarii serviani a Virgilio, in Santini Stok 2004, p. 33-44.

Rand 1916 = E. K. Rand, Is Donatus's Commentary on Virgil Lost?, in CQ 10, 1916, p. 158-164.

Rich forthcoming = J.W. Rich, The origins of Roman annalistic historical writing, in K. Sandberg, C. Smith, Omnium Annalium Monumenta, forthcoming.

Roma. Romolo, Remo e la fondazione della città $2000=$ A. Carandini, R. Cappelli (ed.) Roma. Romolo, Remo e la fondazione della città : Roma, Museo Nazionale Romano, Terme di Diocleziano, 28 giugno-29 ottobre 2000, Rome, 2000.

$R R C=$ M.H. Crawford, Roman Republican Coinage, Cambridge, 1974.

Rudd $1976=$ N. Rudd, Lines of enquiry. Studies in Latin poetry, Cambridge, 1976.

Russo 2010 = F. Russo, Il motivo della consanguinitas tra Romani ed Italici nella propaganda graccana, dans Atene e Roma, 2010, p. 178-196.

Santini - Stok $2004=$ C. Santini, F. Stok, Hinc Italae gentes. Geopolitica ed etnografia dell'Italia nel commento di Servio all'Eneide, Pisa, 2004.

Santini 2004 = C. Santini, Il verosimile e l'illusorio. Un profilo tra indagine antiquaria e critica letteraria sugli Etruschi nei commenti di Servio all'Eneide, in Santini - Stok 2004, p. 163-214.

Santini $2008=$ C. Santini, Virgil as an Etruscologist in Servius' Commentary, or: From the Author to S Author, in Casali - Stok 2008, p. 78-92.

Scarcia $2004=$ R. Scarcia, Il caso Camilla, in Santini - Stok 2004, p. 215-234.

Sharrock $2008=$ A. Sharrock, Aemulatio. The critic as intertext, in Casali - Stok 2008, p. 7-23.

Skempis - Ziogas 2013 = M. Skempis, I. Ziogas (ed.) Geography, Topography, Landscape. Configurations of Space in Greek and Roman Epic, Berlin, 2013. 
Servius, Cato the Elder and Virgil

100 Christopher SмIтH

Stok 2004 = F. Stok, Servio e la geopolitica della Guerra italica, in Santini - Stok 2004, p. 111-162.

Thomas $1982=$ R.F. Thomas, Lands and Peoples in Roman Poetry: the Ethnographic Tradition, Cambridge, 1982.

Torelli 1984 = M. Torelli, Lavinio e Roma. Riti iniziatici e matrimonio tra archeologia e storia, Rome, 1984.

Traina 1993-1994 = G. Traina, Roma e l'Italia: tradizioni locali e letteratura antiquaria (II a.C.-II d.C.), in RAL s. 9.4 (1993), p. 585-636; 9.5 (1994), p. 87-118.
Vanotti 1995 = G. Vanotti, L'altro Enea. La testimonianza di Dionigi di Alicarnasso, Rome, 1995.

Williams $2001=$ J.H.C. Williams, Beyond the Rubicon: Romans and Gauls in Republican Italy, Oxford, 2001.

Ziolkowski - Putnam 2008 = J.M. Ziolkowski, M.C.J. Putnam (ed.) The Virgilian first fifteen hundred years, New Haven, 2008. 